\title{
Virtu@1-ApS: Technological Support for Virtual Service-Learning
}

\section{(Virtu@l-ApS: Soporte Tecnológico para el Aprendizaje-Servicio Virtual)}

\author{
Ángeles Manjarrés Riesco \\ Universidad Nacional de Educación a Distancia, UNED (Spain) \\ Simon James Pickin \\ Universidad Complutense de Madrid, UCM (Spain) \\ Héctor Alonso Meana \\ Siemens Logistics S.L. (Spain) \\ Natalia Rodríguez Fernández \\ Social Services, Las Regueras, Candamo -Asturias-y Asociación Centro Trama \\ (Spain)
}

DOI: http://dx.doi.org/10.5944/ried.23.1.24397

\section{How to reference this article:}

Manjarrés Riesco, A., Pickin, S. J., Meana, H. A., Rodríguez Fernández, N. (2020). Virtu@l-ApS: Technological Support for Virtual Service-Learning. RIED. Revista Iberoamericana de Educación a Distancia, 23(1), pp. 85-109. doi: http://dx.doi. org/10.5944/ried.23.1.24397

\begin{abstract}
Virtual Service Learning (VSL) is Service Learning (SL) mediated by ICTs (Information and Communication Technologies) - both for the provision of the service, and for the support, monitoring and assessment of the learning by teachers - and conceived for situations in which face-to-face communication between students, teachers and beneficiaries of the service is not practicable. Experience has shown that a web application for the support of VSL (and more generally, of SL) would be of great interest. Here, we present the development of such a web application: Virtu@l-ApS (from Aprendizaje-Servicio, SL in Spanish). To date, this software-development project has been carried out in the context of two collaborative and interdisciplinary UNED (Universidad Nacional de Educación a Distancia, the Spanish national distance-learning university) bachelor's degree projects, from the Social Education and Computer Engineering degrees, respectively. Though the currently-available version of the web application lacks important functionality, the experience of developing it has been extremely useful, in particular, in helping to clarify the requirements for a fully operational application which we expect will contribute to the support and expansion of SL in the Spanish higher education sector.
\end{abstract}


Keywords: higher education; information and communication technologies; educational innovation; project methods; service learning, civics.

\section{Resumen}

El Aprendizaje-Servicio Virtual (ApSV) es el Aprendizaje-Servicio (ApS) mediado por las TIC (Tecnologías de la Información y la Comunicación) -tanto para la prestación del servicio como para el apoyo, monitorización y evaluación del aprendizaje por parte de los docentes- y concebido para situaciones en que la comunicación cara a cara entre estudiantes, profesores y beneficiarios del servicio no es posible. La experiencia ha demostrado que sería de gran interés disponer de una aplicación web para el soporte del ApSV (y, en general, de ApS). Presentamos aquí el desarrollo de dicha aplicación web: Virtu@l-ApS. Hasta la fecha, este proyecto de desarrollo de software se ha llevado a cabo en el marco de dos Proyectos de Fin de Grado colaborativos e interdisciplinares de la Universidad Nacional de Educación a Distancia (UNED), de los grados en Educación Social e Ingeniería Informática, respectivamente. Aunque la versión de la aplicación web actualmente disponible carece de importantes funcionalidades, la experiencia de su desarrollo ha sido extremadamente útil, en particular, para la clarificación de los requisitos de una aplicación real, completamente operativa, que esperamos contribuya al soporte y la expansión del ApS en la Enseñanza Superior en España.

Palabras clave: enseñanza superior; tecnologías de la información y de la comunicación; innovación pedagógica; método de proyectos; aprendizaje servicio; educación cívica.

COETIC is a UNED interdisciplinary research group focused on teacher innovation for the development of ethical and civic competences and communitybased methodologies in higher education (see https://blogs.uned.es/coetic/) that brings together lecturers from different Spanish universities with a wide-ranging experience in pedagogical innovation in these topics. Since the 2014/15 academic year, its main focus of interest has been VSL, also called e-Service Learning, i.e. SL that takes place in virtual spaces (García-Gutiérrez, Ruiz-Corbella \& del Pozo Armentia, 2017; Nielsen, 2016; Purcell, 2017; Waldern, McGorry \& Widener, 2012) without the parties involved - students, teachers and the communities receiving the service - sharing the same physical space. In the last few years, COETIC has run several pilot experiments in different Faculties of the UNED.

VSL enables UNED distance-learning students who cannot participate in local SL projects to participate in SL programmes.

Since VSL has to be mediated by ICTs, both for the provision of the service, and for the support, monitoring and assessment of the learning by teachers, COETIC has proposed the development of not only methodological but also technological tools to support this pedagogical approach.

In the academic year 2016/17 COETIC launched a development project for a web application to support and promote VSL: Virtu@l-ApS. Earlier pilot COETIC VSL 
projects that were designed to explore the possibilities of VSL in distance-learning higher-education institutions also served to identify the requirements of this web application.

The web-application development was conceived in itself as a VSL project in which students from different disciplines would participate. The application is designed to organise and centralise resources on SL, to facilitate collaboration among different actors (students, lecturers and universities, as well as NGOs and various types of community organizations), and to support the Spanish higher-education SL community, in both the face-to-face and distance-learning modalities. The objective is to promote and support VSL educational activities in various academic contexts (bachelor's degree projects, master's degree projects/theses, doctoral theses, internships, etc.) and teaching areas (engineering, law, education, sciences, for example).

\section{BACKGROUND: Virtu@l-ApS PRECURSORS}

The experience of teachers who have undertaken, or tried to undertake SL initiatives in higher education in Spain, shows that many project proposals do not reach fruition because of the difficulty in matching offers with requests; that is to say, matching the didactic and organizational needs of the educational institution that wants to provide a service, with the needs and availability of the organization or community that wants to receive a service. Jacoby (2014) highlights the complexity, dynamism and fragility of the partnership relationships in SL, as well as the time and energy required to establish and maintain them, the compatibility of the recipient communities and educational institutions at multiple levels being a key aspect in this regard. By way of illustration, an attempt by one of the authors to provide an SL service to Médicos del Mundo failed due to the NGO staff's lack of understanding of what constitutes a suitable task for a bachelor's degree project and their lack of availability to clarify this point with the lecturers.

As lecturers with a certain amount of experience in development SL projects, both in the local sphere and in the international cooperation context, we realised some time ago that good computer support could be of great help in the difficult task of matching supply and demand of SL. This support could facilitate the identification of potential partnerships as well as the collaboration between the potential service provider and receiver in the task of refining an initial idea and turning it into a realistic project proposal that meets the needs of both parties. Additionally, this computer support could serve to guide and coordinate the work of the different stages of SL projects already underway, providing a formal framework for their development. Such a framework would promote a systematic and rigorous approach to SL methodologies, facilitating the monitoring and continuous evaluation of the students and of their learning, as well as that of the SL projects themselves. This monitoring and evaluation is particularly important for the implementation of VSL 
in distance-learning institutions. Although in Spain and in many other countries there are web communities dedicated to the promotion of SL, where events are publicized and experiences and resources related to SL are shared (e.g. the website of the Spanish SL network, Red española de aprendizaje-servicio: https:// aprendizajeservicio.net/), as far as we know, there is no community dedicated specifically to the higher education sector, nor is there any computer application that provides the aforementioned functionalities.

Heras et al (2017) like Ruiz-Corbella and García-Gutierrez (2019) point out that SL programs, which are already well established on the American continent, only recently began to gain strength in European, and in particular Spanish, educational institutions. The first SL projects started in Spain towards the end of the 90s. The scant academic value attributed until now to SL practice outside the field of pedagogical studies has been the reason why attempts to develop a computer application such as the one described have always emerged in the context of bachelor's degree projects.

To our knowledge, the first attempt to develop an application of the type described above was that of Parmentier (2004), carried out at the Polytechnic University of Madrid (UPM). Due to the fact that the application developed required human resources for its deployment and administration, it never came to be used. Starting from the work of Parmentier (2004), as lecturers of the Complutense University of Madrid (UCM) and the UNED, we relaunched the idea in the bachelor's degree project of Lozano (2015), in which a web application, based on the well-known content management framework (CMF) Drupal (see https://www.drupal.org/) was developed. However, the resulting prototype was quite basic and incomplete, with technical constraints that limited its functionality.

In summary, the two web applications for SL support developed since 2004 were never deployed due to a lack of resources for finishing their development, as well as for guaranteeing their operation and maintenance. There is no doubt, however, of the interest of such an application, given the growing expansion of the SL methodology in the Spanish higher education sector. We also believe that involving students in the development of this application while giving this involvement an SL character is also of great interest, given the multidisciplinary nature of the apprenticeships this teaching methodology entails and its character of being a real project incorporating community intervention. As well as learning about computing engineering, the students learn about SL as a pedagogical approach, ethics and civic engagement and gain some understanding of the third sector.

Under the auspices of COETIC, we returned to the objective of creating an SLsupport application via two UNED bachelor's degree projects: Rodriguez (2017), a Social Education degree project, and Alonso (2018), a Computing Engineering degree project. The first focused on the specification of an application for the support of SL and, in particular VSL. The second completed the technical aspects of the specification defined in Rodriguez (2017), providing a detailed softwareengineering requirements specification, before designing and implementing 
the basic functionality of the application, building on the work of Lozano (2015). However, the Drupal components used in the latter project were found to be much less open to customisation than expected, this fact considerably reducing the interest of a Drupal-based development path. Alonso therefore developed an application from scratch based on the well-known Javascript environment Node.js (see https:// nodejs.org/en/), widely used in modern web applications.

Although the title of Alonso's bachelor's degree project (Alonso, 2018) refers to "virtual" SL, the application is designed to provide services to the whole SL community. However, Virtu@l-ApS is not yet operational since the current implementation is more of a prototype and, in particular, does not cover all the basic functionalities required. Its further development and deployment is the subject of an ongoing collaboration between COETIC and the Sistemas Informáticos y Computación department of the UCM.

\section{METHODOLOGY}

Development of an SL-support application, being an SL project in which the intended beneficiary of the service is the SL community itself, could be said to be an SL meta-project. Since the aims of such an application are to promote the setting up and launching of SL interventions, to facilitate their implementation and operation, and to increase their utility and impact, the intended beneficiaries of the work of the SL community, i.e. disadvantaged and excluded populations, can also be considered to be intended beneficiaries of this meta-project.

The bachelor's degree projects described in the previous paragraphs, were conceived and developed themselves as SL projects, involving different SL learning experiences. The students had to delve into the knowledge of SL methodology, to study first hand various SL experiences, to dialogue with NGOs and members of the academic community involved in SL, etc. The authors of Rodríguez (2017) and Alonso (2018), developed their projects in close collaboration, thereby contributing to multidisciplinary learning. Both students authors of this article, valued their experience very positively and recognised the contribution of this experience to the development of their ethical-civic awareness and their knowledge of the reality of the beneficiary community. The SL methodology is characterized by being experiential (Kolb, 2014), participatory and reflective (Schön, 1990) and performed in situated contexts (Dewey, 2004). The above-mentioned projects had many but not all of these aspects. Starting from the identification of a need of a community, an intervention to meet this need was planned, and this intervention took place in one of the beneficiaries' context, by means of an intentional and systematic teaching process with a strong curricular base. 
The project was carried out broadly following the characteristic phases of a typical SL methodology, see (Jacoby 2016):

1. establishment of partnership relationships;

2. specification of the service and requirements for its provision;

3. project development;

4. learning assessment;

5. SL impact assessment.

\section{Establishment of partnership relationships}

Viewing the construction of Virtu@l-ApS as an SL project, the community partner is the SL community itself, constituted, firstly, by providers of SL services in the educational community and, secondly, by beneficiaries of SL services such as NGOs, associations and other third sector organisations, and through these organisations, disadvantaged and excluded populations.

In the ongoing development, partnership relationships will be established with possible future beneficiaries of SL services by asking representatives of thirdsector organisations to participate in the development of the application, at least in its validation and verification $(\mathrm{V} \& \mathrm{~V})$ and hopefully also in the elicitation of additional requirements. However, in the software developments reported on above, relationships were only established with members of the educational community and, in the case of Lozano (2015) and Alonso (2018), only with the supervisors of the projects who, as well as supervising, played the role of SL community members, not only of the SL provider type but also of the SL beneficiary type, by drawing on years of experience of voluntary work in a technology-oriented NGO. Regarding the logistical aspects, the communication among lecturers and students was carried out largely asynchronously, by virtual means.

\section{Specification of the service and the requirements for its provision}

Viewing the construction of Virtu@l-ApS as an SL project, the major part of the specification of the service to be provided to the community is the specification of the application itself.

The initial requirements of the application were defined in the Social Education degree project of Rodríguez (2017). The objectives of this project were as follows:

1. to conduct a thorough investigation of institutions, universities, associations, etc. dedicated to promoting, researching and developing SL activities at national and international level;

2. to demarcate and specify the SL concept; 
3. to collect information relevant to providing content for Virtu@l-ApS;

4. based on all the above, to provide a first approach to the web design of Virtu@lApS (areas organization, navigation, etc) and its functionalities from a user perspective, and to provide content (headlines, information to present on the pages, resources, forms designed for collecting information from organizations requiring services, etc).

The detailed requirements specification of the application was drawn up in the Computer Engineering degree project of Alonso (2018), taking into account the work of Rodríguez (2017)and Lozano (2015).

The requirements for the provision of the service were not addressed in the development of Virtu@l-ApS carried out so far but will be addressed in the new project.

\section{Project development}

Viewing the construction of Virtu@l-ApS as an SL project, the major part of the development of this SL project is the development of the application itself.

During the academic year 2016/17, the UNED lecturers and students involved held virtual meetings to define the functionalities of Virtu@l-ApS and to discuss its viability, based on their experience of more than 10 years in SL projects in both the face-to-face and distance education context. These functionalities were then prioritized with a view to including those of highest priority in the first prototype.

Pilot VSL projects that had been promoted and implemented by COETIC in different UNED degrees in previous years (García Gutiérrez et al., 2016) have provided feedback for the specification of the Virtu@l-ApS functionality. Of particular interest was the part of these VSL projects carried out in the context of the "Artificial Intelligence Applications for Human and Sustainable Development" course of the Master of Science (MSc) in "Advanced Artificial Intelligence: Fundamentals, Methods and Applications" (Manjarrés \& Pickin, 2018) in the academic years 2016/17, 2017/18 and 2018/19. The AI MSc part of these VSL projects helped to clarify the technological needs that arise when SL involves computer engineering processes.

The objective of the above-mentioned projects, carried out in collaboration with the universities of Porto Novo (Benin) and Strathmore (Kenya), was to explore the training possibilities of SL in distance learning, with emphasis on:

- the development of competences for global citizenship and intercultural dialogue,

- the virtual approach in an international context,

- the technological mediation in the development of learning and service provision. 
The VSL of these projects consisted of online interview sessions in which African students practiced their spoken Spanish with UNED students, who in turn practiced different professional competences. Thus, in the case of the AI MSc students, the interviews were part of a requirements-engineering process aimed at the development of customisable online learning environments, adapted to the idiosyncrasy of the educational context and the needs of the students, taking an ethical and human rights approach. The students faced the task of identifying the relevant factors for developing such an educational environment (personal, community, cultural, ethical, economic and social factors, pedagogical and organizational practices, resources that condition viability and sustainability, foreseeable impact, etc.), as well as identifying suitable indicators for evaluating its success.

The analysis of these VSL projects has served to refine the VSL methodology (work dynamics, structure of the project memories and "Field Notebook", evaluation criteria, etc.), and to identify methodological and technological tools both for the support of VSL projects and for their monitoring and evaluation by teachers, thereby provided feedback for the specification of the Virtu@l-ApS functionality, as already stated. It has also enabled the identification of discipline-specific methods and tools that could be incorporated into Virtu@l-ApS, for example, for cooperation for development projects the Logical Framework (USAID, 1970), and for computer engineering projects computer development methodologies focused on capturing the user's perspective.

The Computer Engineering lecturers were in charge of supervising the development of the web application. The initial requirements were prioritised with the aim of using them to guide an iterative and incremental development (IID) process, this type of development methodology being well suited to the circumstances of our project. In an IID process, the application is built in successive cycles, each starting with an analysis and requirements-engineering phase using the requirements that correspond to that cycle. Each cycle then continues with its risk analysis, design, implementation and validation phases and finishes with a working application. IID is a well-used practice in software engineering, one of its main benefits being the management of uncertainty in costs and in available resources. In a nutshell, when the assigned budget is close to being used up, on finishing the current cycle the development is terminated, resulting in an application (possibly with reduced functionality) ready to be used.

Finally, all the lecturers involved in the project participated in the validation of the application, testing the application as a potential user in order to detect problems and weaknesses, and to assess its usability.

\section{Learning assessment}

We classify the teaching objectives of our rather unusual meta-SL program according to Jacoby (2014) and Ruiz-Corbella and Manjarrés (2019): 
- Application of knowledge and concepts, and practice of curricula competences in a real context. In this case, in which the most relevant competences will be software engineering and community-based research competences, this objective is carried out by putting into practice software engineering approaches such as "user-centered", "community-based", "context-oriented", "participatory", "sensitive to cultural aspects", etc.

- Practice of complex problem-solving skills with understanding of the associated social problems.

- Practice of oral and written communication skills.

- Practice of collaborative work skills.

- Development of generic competences, attributable in fact, to any SL projects, among which we highlight personal, interpersonal and ethical competences; and cognitive and metacognitive competences. We place an emphasis on criticalthinking competences. In the professional field, critical reflection will focus on whether the computer application developed does indeed satisfy the objectives. Finally, the content of the project will inevitably force the student to delve into the concept of SL and its potential as a tool for social transformation, as well as to rethink their professional goals from a wider perspective.

The curricular competences were assessed by the usual procedures for bachelor's degree projects. This aspect of our SL project did not pose any difficulties, since the connection between the project activities and the curricular contents involved was clear.

The assessment of other types of competences usually linked to SL projects is a complex task and, as pointed out by Ruiz-Corbella and Manjarrés (2019) cannot be carried out using a unique formula. Ruiz-Corbella and Manjarrés (2019) identified criteria and instruments that guarantee quality assessment and contribute to the systematisation of SL practices. Studies compiling the instruments available for the assessment of personal and cognitive competences (Rama et al., 2000) and of metacognitive competences, such as application of knowledge, critical thinking, resolution of problems and intellectual development, can be found in the literature (Steinke and Fitch, 2007). In particular, in the engineering domain literature, interesting assessment tools linked to the technical competences specified by ABET (see https://www.abet.org/) and widely used in SL programs are reported on in (Cummings et al., 2013).

In the Virtu@l-ApS development carried out so far, a rigorous assessment of specific SL competences has not been performed. We have only reflected at a qualitative level on this issue, without our conclusions having any impact on the students' grades. In the context of the recently-launched new project we are conducting a review of the above-referenced literature to select the assessment instruments that best fit our meta-SL approach. In this new project, a greater number of students will be involved, the project will include the assessment of the SL competences acquired 
by these students, and the project will conclude with the real deployment of Virtu@lApS and an assessment of its impact on the SL community.

\section{SL impact assessment}

Logically, since we have only produced an initial prototype, it has not been possibleto assess the impact of Virtu@l-ApS on the SL community. In lieu of such a full assessment, we involved COETIC lecturers with experience in SL in the validation of the application and collected their impressions about the potential usefulness of Virtu@l-ApS. We present these impressions in the following section.

\section{RESULTS OF THE SERVICE PROVIDED}

The result of the SL project service is constituted by a specification of the functionality of Virtu@l-ApS and a first prototype of this application, as well as by the results of the SL impact assessment. Note that the specification of the functionality of an application is generally considered to be, in itself, a valuable artifact in software engineering.

\section{Functionality specification for Virtu@1-ApS}

Below we list the functionalities identified, grouped into different areas.

\section{Basic functionalities}

- An area of registered users in which different profiles are defined for the different actors (teacher, student, service beneficiary,...). The user's profile determines his or her subscription, search and publication capabilities, and the private project spaces to which he or she has access, which will include those of the projects in which he or she is participating. Interactions between users are to be carried out through web forms, forums and email. For example, NGOs may offer topics for projects, students may express their interest in participating in projects, lecturers may offer to tutor them, supervise them, or co-supervise them with NGO staff or companies, etc. The possibilities considered when designing the application are very diverse. 
Functionalities to support the higher education SL community in the sharing of experience and all kinds of resources, as well as the basic functionalities for establishing the initial contract between possible partners

- Services for the publication of experience, initiatives and material of all kinds related to VSL in higher education.

- Services for the dissemination of offers and requests for participation in SL project proposals.

Functionalities to support the definition of SL projects and, especially, VSL projects

- A service connecting requests and offers of participation in SL projects, which provides:

- Search for requests or offers with the possibility of filtering according to different characteristics, where both the search and the filtering possibilities depend on the user's profile.

- Subscription to receive notices about offers or demands in a certain area of interest, where the subscription possibilities also depend on the user's profile.

- Automatic sending of notifications of offers in an area of interest or requests in an area of interest, according to subscription and depending on profile, when new information about this area arrives.

- Support for the parties involved in SL project proposals to refine them and make them more concrete:

- Through connection to, or integration of, software tools for the support of collaborative work such as tools for videoconferencing or audioconferencing, cooperative edition, shared blackboard, shared screen, wiki, chat, calendar (and the forums that are already integrated in the current prototype).

- Support for the generation of official documentation for an SL project whose definition is finalized, in particular, the request for recognition and possible subsidy of the SL project by the educational institution involved. Necessarily, this support must be customised for each participating organisation. 


\section{Functionalities to support the development of SL projects}

- Connection to, or integration of, software tools for the support of collaborative work, as well as tools for the support of software project management, which facilitate planning, task assignment, generation of reports, etc.

- Provision of a formal framework to guide a development in coherence with SL methodologies, thus favouring its systematic application and the delimitation of roles of the different actors involved. The tools for collaborative work and project management should be adapted to assist the processes and work dynamics characteristic of SL. As an example, we mention that it could be useful to adapt the logframer tool (http://www.logframer.eu), based on The Logical Framework project development methodology (USAID, 1970).

- Possible integration of support tools for project development in specific disciplines, selecting those that are in coherence with the principles and pedagogical objectives of SL. By way of example, regarding software development projects, attention should be paid to design support tools that are "usercentered", "community-based", "context-oriented", "participatory", "sensitive to cultural aspects", etc.

\section{Functionalities for the support of teaching work}

- Support for assessment, both of students and of SL projects:

- Connecting project activities with curricular content.

- Suggesting assessment criteria and tools appropriate to each case.

- Including selected rubrics from those referenced in the SL literature

- Providing support for alternative assessment tools as discussion groups.

- Integrating online questionnaires, designed and validated according to recognised methodological practices, for several different purposes including attitude towards SL, and assessment both of the students' competences and of the SL projects, on the part of all the actors involved, etc.

\section{Resource management functionalities}

- Support for the management of the SL project proposal and project versions, through a version control system (to control versions of the code in the case of software engineering projects).

- Support for project tracking, through tools that automatically generate reports of activities carried out using the collaboration tools and of the submission of project documentation. Automatic tracking tools and assessment tools based on the tracking information would also provide continuous feedback to the students. 


\section{Functionality for the usability of the application}

- A recommendation module (as a basic chatbot-like virtual assistant), which guides the members of the SL community through the different phases of an SL action, in the case of students, for example, starting with helping them to choose a suitable project, adapted to their interests and personal profile.

\section{Other needs}

- Forums and blogs.

- Access to a document repository on VSL, which should include academic articles, multimedia pedagogical resources, project reports, etc.

- Documentation, in particular user manuals (one for teachers, another for students, another for third parties).

\section{First prototype of Virtu@1-ApS}

The first prototype of Virtu@l-ApS, developed by Alonso (2018), provides the following main functionalities:

- Services for the publication of experiences, initiatives and material of all kinds related to VSL in the University, as well as offers and requests for participation in specific projects.

- Forums and blogs.

- Access to a VSL document repository, which would include academic articles, multimedia pedagogical resources, project reports, etc., and a respository of SL experiences.

- Area of registered users with different profiles for the different actors.

The other functionalities identified above are pending implementation. In Figure 1, we show schematically the architecture and main technologies underlying Virtu@l-ApS. Figure 2 shows the SL project cycle supported by the current version of Virtu@l-ApS. Table 1 summarizes the services provided according to the different user profiles. To illustrate the interface of the current version of Virtu@l-ApS, Figures 3 and 4 show, respectively, a screen dump where the information of a call for participation in an SL project is presented and the implementation of the SL proposal definition service that the application provides to the lecturers. Figure 5 illustrates the repository of SL experiences and the ability of community members to provide bibliographic resources. Figure 6 shows a screen dump in which the SL projects in progress are listed. Finally, in Figure 7 the forms for the registration of new users are shown. We will not describe here the technical aspects of the engineering process, which can be consulted in (Alonso, 2018). 


\section{SL impact assessment results}

The impressions of the COETIC lecturers about the potential usefulness of Virtu@l-ApS were as follows:

- The promotion of SL programmes and the institutional support for their development are still very weak in Spain. An application to support the educational community involved in SL projects that provided the specified functionalities could contribute to the success of SL initiatives and the expansion of their use in higher education.

- Virtu@l-ApS could also be extremely useful for gathering valuable data for defining a systematic approach to SL, and for research in SL (on the academic impact of different modalities, the suitability of different evaluation techniques, the competences involved, etc.).

- It would also contribute to formalizing SL methodologies, monitoring learning, and providing rigor in the assessment of competences, facilitating the continuous observation and assessment of the students, the continuous monitoring of the project and feedback about the project progress.

- It would be extremely useful for the application to incorporate tools based on validated rubrics that guide and support the rigorous evaluation of curricular competences as well as other difficult-to-measure competences that are relevant to SL.

Figure 1. Virtu@l-ApS: architecture and main underlying technologies

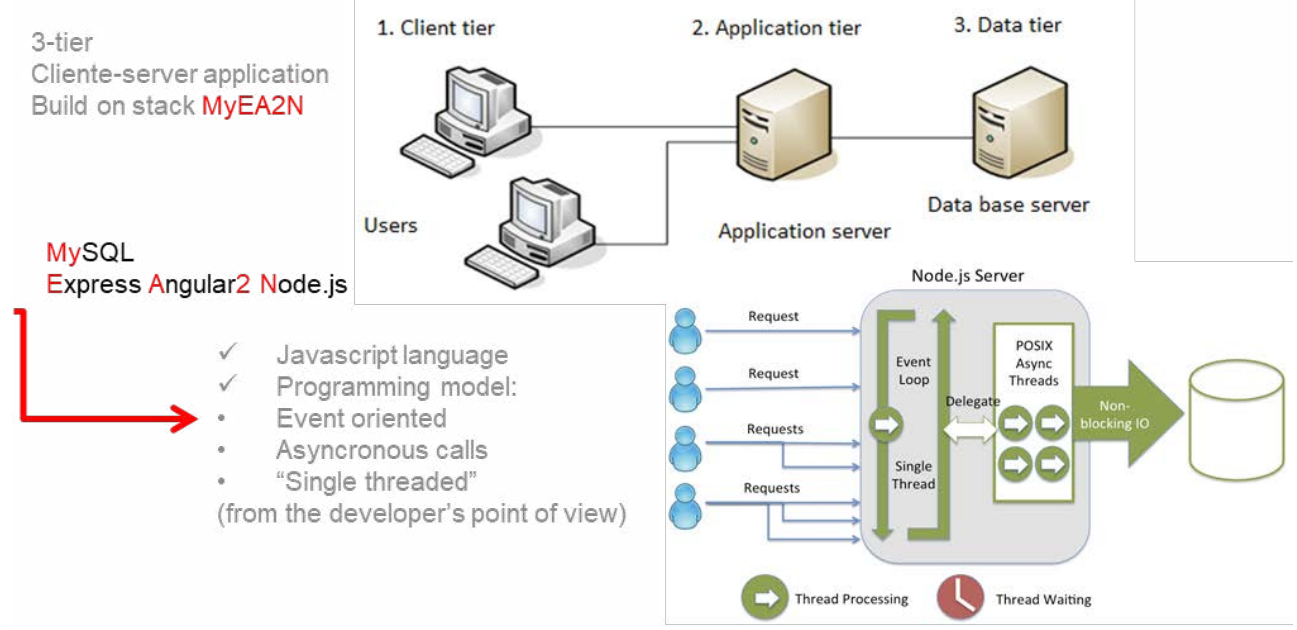


A. Manjarrés; S. James Pickin; H. Alonso Meana; N. Rodríguez FernándeZ

Virtu@L-ApS: Technological Support for VirTual Service-LearNing

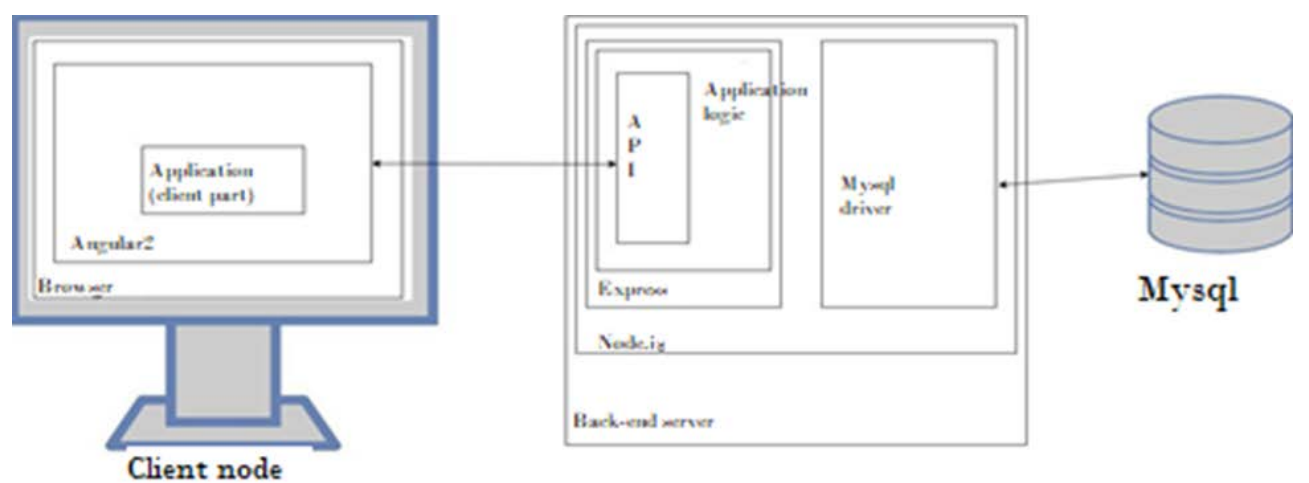

Figure 2. SL Project cycle supported by Virtu@l-ApS

\section{uned ApS Virtual}

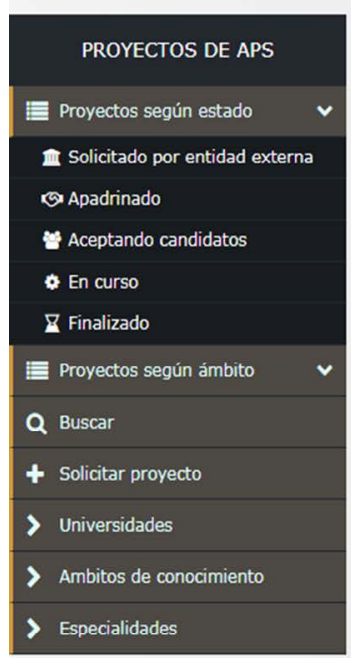

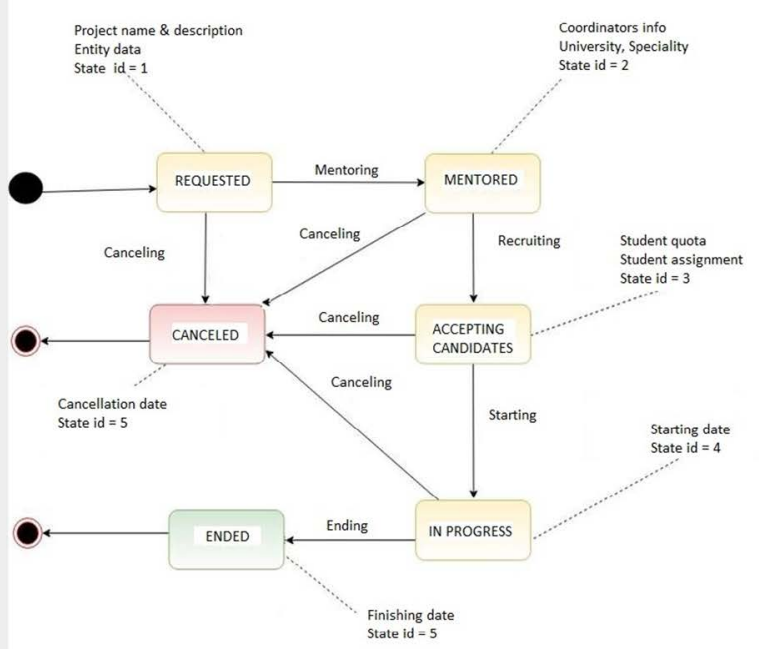


Tabla 1. Services provided according to the different user profiles

\begin{tabular}{|c|c|c|c|c|c|c|c|}
\hline & Actions & \begin{tabular}{|c|} 
Visitor \\
$\mathrm{x}$
\end{tabular} & Student & \begin{tabular}{|c|} 
Lecturer \\
$\mathrm{x}$
\end{tabular} & Entity & $\begin{array}{c}\text { University } \\
\mathrm{x}\end{array}$ & Adm. \\
\hline SL projects & $\begin{array}{l}\text { Create request } \\
\text { Update mentoring } \\
\text { Update recruitment } \\
\text { Update start } \\
\text { Update end } \\
\text { Update cancelation } \\
\text { Consult request } \\
\text { Consult recruitment } \\
\text { Consult started } \\
\text { Consult ended } \\
\text { Consult canceled } \\
\end{array}$ & $\begin{array}{l}X \\
X \\
X\end{array}$ & $\begin{array}{l}X \\
X \\
X\end{array}$ & $\begin{array}{l}X \\
X \\
X \\
X \\
X \\
X \\
X \\
X\end{array}$ & $\begin{array}{l}\mathrm{X} \\
\mathrm{X} \\
\mathrm{X}\end{array}$ & $\begin{array}{l}X \\
X \\
X \\
X \\
X \\
X \\
X \\
X \\
X \\
X \\
X\end{array}$ & $\begin{array}{l}X \\
X \\
X \\
X \\
X \\
X \\
X \\
X \\
X \\
X \\
X\end{array}$ \\
\hline $\begin{array}{l}\text { Historical } \\
\text { archive } \\
\text { (previous } \\
\text { projects) }\end{array}$ & \begin{tabular}{|l|} 
Consult \\
Create \\
Update \\
Detele \\
\end{tabular} & $\mathrm{X}$ & $\mathrm{X}$ & $\begin{array}{l}X \\
X \\
X \\
X\end{array}$ & $\mathrm{X}$ & $\begin{array}{l}X \\
X \\
X \\
X\end{array}$ & $\begin{array}{l}X \\
X \\
X \\
X\end{array}$ \\
\hline $\begin{array}{l}\text { Data base } \\
\text { (Universities, } \\
\text { degrees...) }\end{array}$ & \begin{tabular}{|l} 
Consult \\
Create \\
Update \\
Detele
\end{tabular} & $\mathrm{X}$ & $\mathrm{X}$ & $\mathrm{X}$ & $\mathrm{X}$ & $\begin{array}{l}X \\
X \\
X \\
X\end{array}$ & $\begin{array}{l}X \\
X \\
X \\
X\end{array}$ \\
\hline Bibliography & \begin{tabular}{|l|} 
Consult \\
Create \\
Update \\
Detele \\
\end{tabular} & $\mathrm{X}$ & $\mathrm{X}$ & $\begin{array}{l}\mathrm{X} \\
\mathrm{X} \\
\mathrm{X} \\
\mathrm{X}\end{array}$ & $\mathrm{X}$ & $\begin{array}{l}X \\
X \\
X \\
X\end{array}$ & $\begin{array}{l}X \\
X \\
X \\
X\end{array}$ \\
\hline Users & $\begin{array}{l}\text { Login } \\
\text { Logout } \\
\text { List users } \\
\text { Register in system } \\
\text { Modify user profile } \\
\text { Recover password } \\
\text { Modify password } \\
\text { Look for a user } \\
\text { Modify user blocking } \\
\text { Activate prime user }\end{array}$ & $\begin{array}{l}\mathrm{X} \\
\mathrm{X}\end{array}$ & $\begin{array}{l}X \\
X \\
X\end{array}$ & $\begin{array}{l}X \\
X \\
X\end{array}$ & $\begin{array}{l}X \\
X \\
X\end{array}$ & $\begin{array}{l}X \\
X \\
X\end{array}$ & $\begin{array}{l}X \\
X \\
X \\
X \\
X \\
X \\
X \\
X\end{array}$ \\
\hline Others & $\begin{array}{l}\text { See interest links } \\
\text { Send contact message } \\
\text { Read privacy polices } \\
\text { Read terms \& cond. } \\
\text { Access social net } \\
\text { profiles }\end{array}$ & $\begin{array}{l}\mathrm{X} \\
\mathrm{X} \\
\mathrm{X} \\
\mathrm{X} \\
\mathrm{X}\end{array}$ & $\begin{array}{l}\text { X } \\
X \\
X \\
X \\
X\end{array}$ & $\begin{array}{l}\mathrm{X} \\
\mathrm{X} \\
\mathrm{X} \\
\mathrm{X} \\
\mathrm{X}\end{array}$ & $\begin{array}{l}\mathrm{X} \\
\mathrm{X} \\
\mathrm{X} \\
\mathrm{X} \\
\mathrm{X}\end{array}$ & $\begin{array}{l}X \\
X \\
X \\
X \\
X\end{array}$ & $\begin{array}{l}\mathrm{X} \\
\mathrm{X} \\
\mathrm{X} \\
\mathrm{X} \\
\mathrm{X}\end{array}$ \\
\hline
\end{tabular}


Figure 3. Screen dump illustrating the presentation of a call for participation in a SL project



Figure 4. SL proposal definition service provided to the lecturers

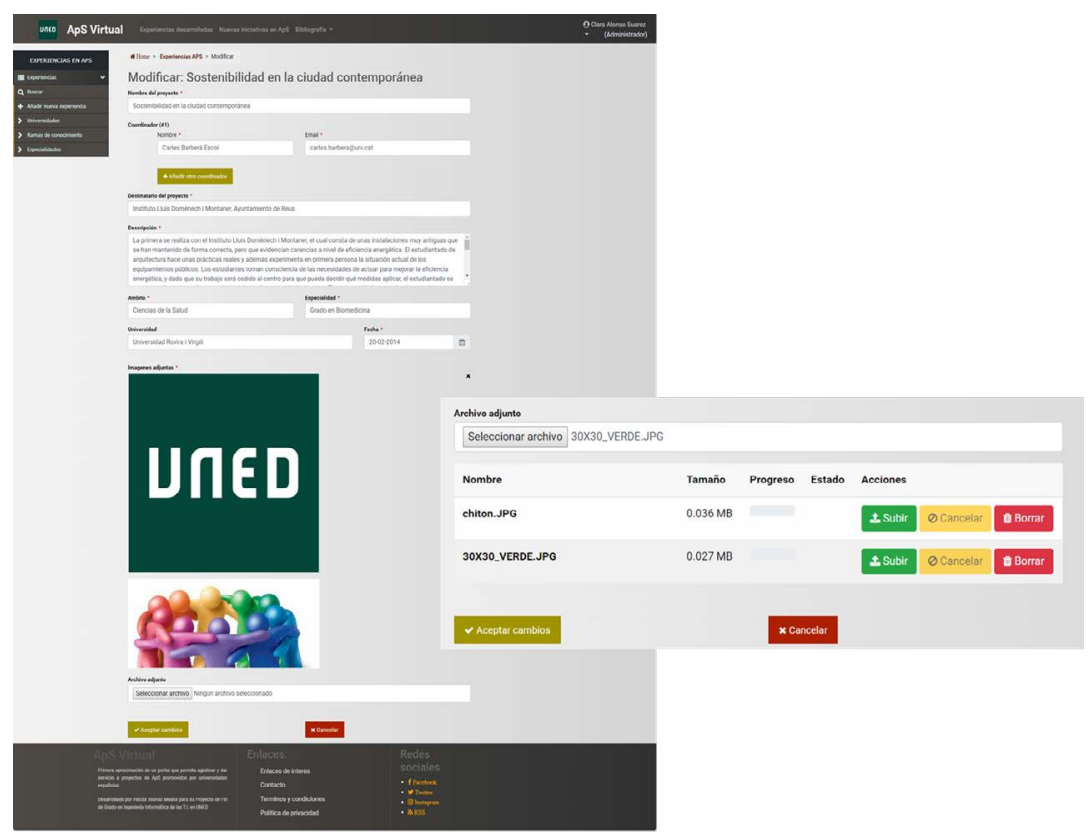


A. Manjarrés; S. James Pickin; H. Alonso Meana; N. Rodríguez Fernández VirTu@L-ApS: Technological Support For Virtual Service-Learning

Figure 5. Experience repository. The community members can provide bibliographic resources to the online document repository

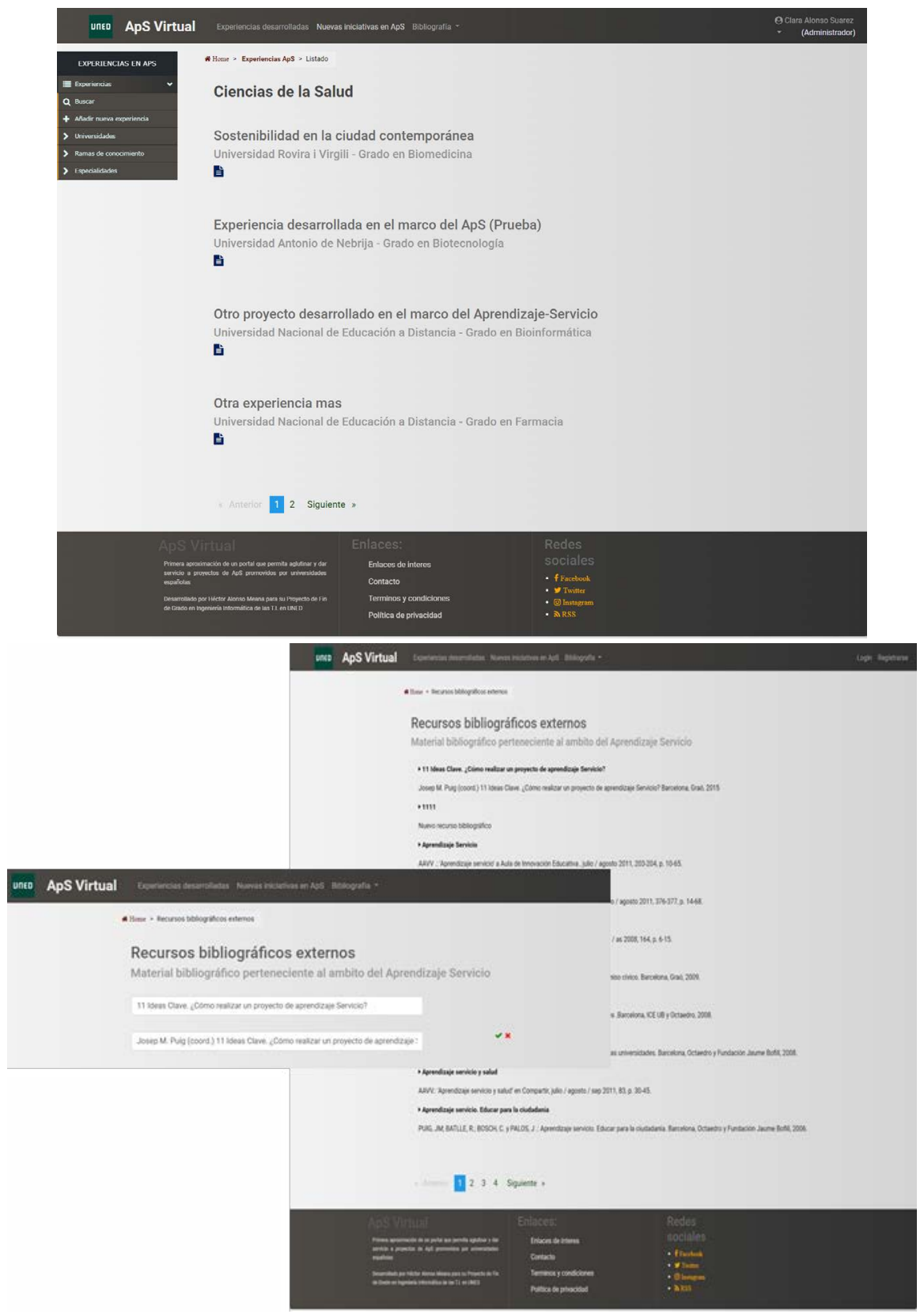


A. Manjarkés; S. James Pickin; H. Alonso Meana; N. Rodríguez FernándeZ

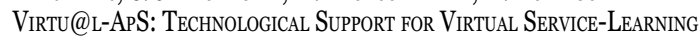

Figure 6. SL projects in progress visualization

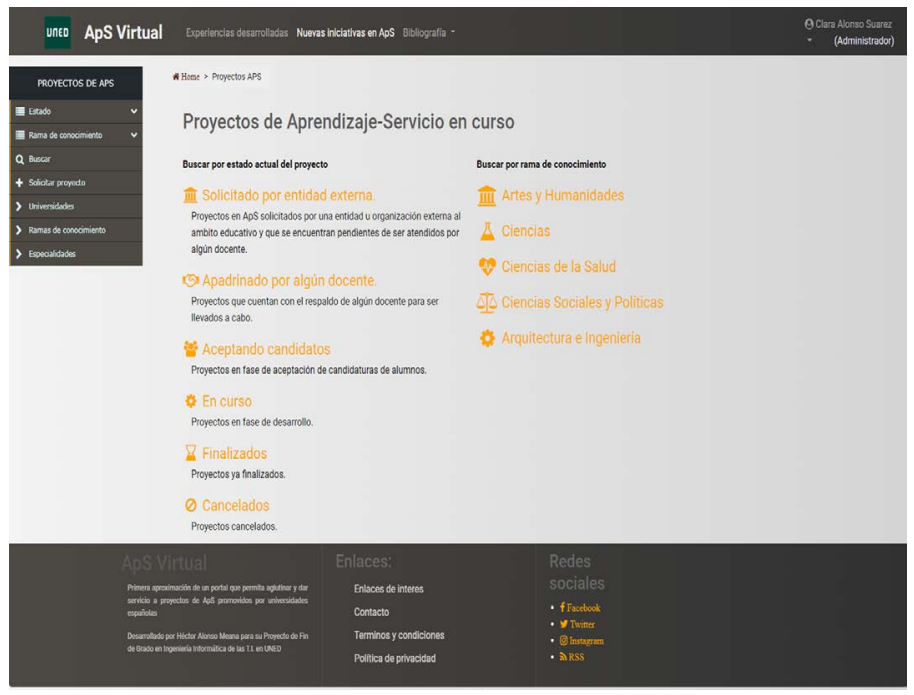

Figure 7. Forms for the registration of new users

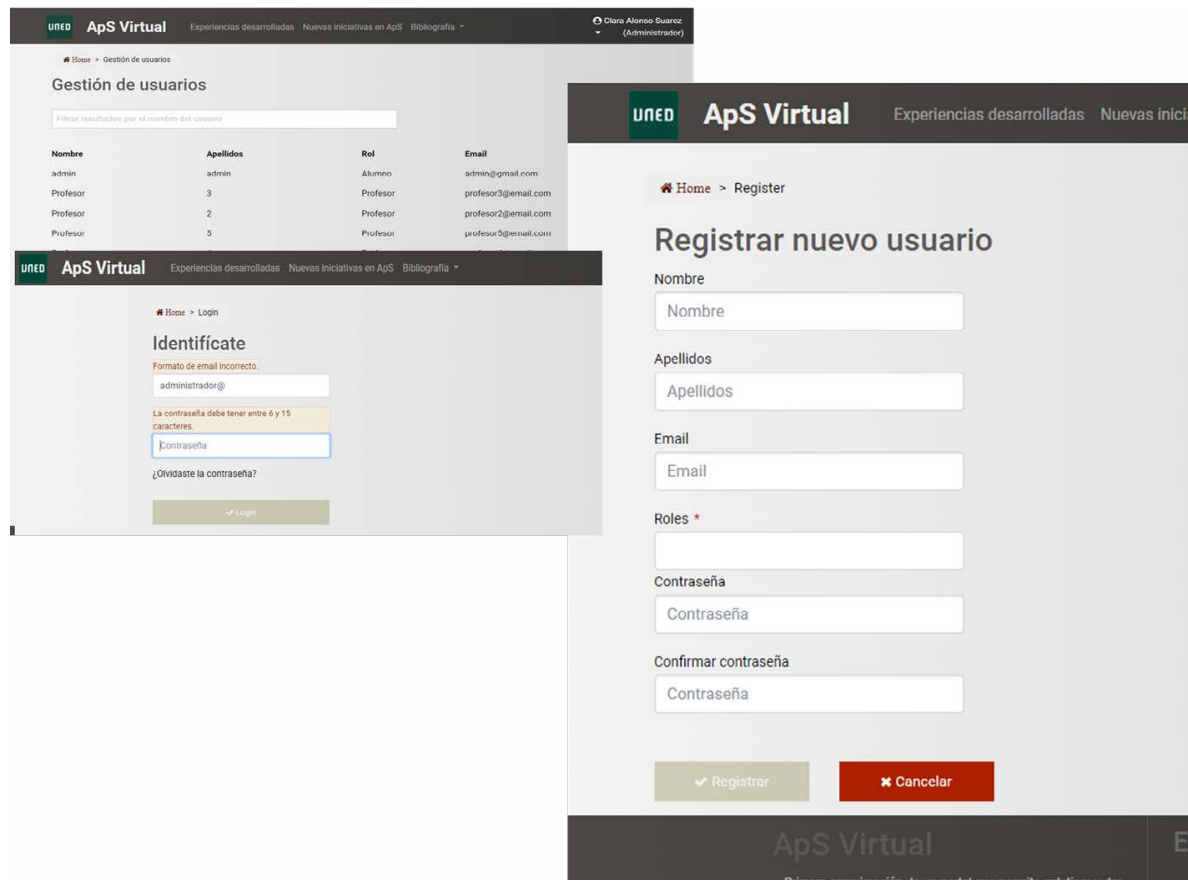




\section{CONCLUSIONS}

In this article, we report on the research and development of a set of technological tools for the promotion and support of SL, and a first version of a prototype SLsupport environment, Virtu@l-ApS, that integrates some of these tools.

SL is a consolidated practice on the American continent and is increasingly being applied in Europe. It is foreseeable that the "virtual" modality (in particular international VSL) will experience an increasing diffusion in the coming years, both in distance and face-to-face universities. In this scenario, as recognized by the lecturers who participated in the validation of the first prototype, the interest of Virtu@l-ApS, a novel application as far as we are aware, is clear.

Ruiz-Corbella and Manjarrés (2019) show that the SL methodology is wellreceived by teachers at all educational levels, despite the fact that institutional support is still, with few exceptions, very weak (Heras Colàs et al., 2017). Evidence of this acceptance can be found in the established SL networks and the numerous scientific meetings dealing with this methodology, which allow us to infer the relevance of our project and its enormous potential impact.

In addition to facilitating virtualization, Virtu@l-ApS would help to formalize SL methodologies, monitor learning, and provide rigor in the assessment of competences, facilitating the continuous observation and assessment of students, the continuous monitoring of the project, and feedback about the project progress.

According to the terminology of Jacoby (2014), different types of assessments can be considered: "qualitative", "direct", and "indirect".

Steinberg, Bringle and Williams (2010) describe assessment by "informal content analysis" and Jacoby (2014), assessment by "observation". See (Cummings et al., 2013) for a definition of the notion of "long term assessment".

As concluded in (Ruiz-Corbella and Manjarrés, 2019) the aforementioned instruments and assessment techniques are complementary and their joint use is recommended in order to carry out a complete evaluation. Although the academic impact on students is supposed to be one of the key objectives of SL, Ruiz-Corbella and Manjarrés (2019) highlight that, in the extensive literature on SL experiences, generally speaking, little attention is paid to the curricular competences developed in these projects, or to the criteria by which these competences are assessed. Frequently, this assessment is based on questionnaires that reflect subjective perceptions, whether those of the student himself or herself, those of classmates, those of teachers or those of the entities that collaborate in the project. Numerous SL researches point out the importance of identifying criteria and reliable instruments for the assessment of curricular competences that guarantee the quality of the SL assessment, and contribute to the systematisation of these educational practices.

In future versions of Virtu@l-ApS, we intend to incorporate tools based on validated rubrics that guide and support the rigorous evaluation of curricular competences as well as other difficult-to-measure competences relevant to SL. 
Such is the case of metacognitive competences (Steinke and Fitch, 2007), personal competences (self-knowledge, self-esteem, motivation for the profession, etc.) (Sánchez-Elvira, 2010) and spiritual competences (Barret, 2016). We recognize the enormous complexity of SL evaluation, as Rubin and Matthews (2013) and Jacoby (2014) point out.

We find it to be of particular interest that the application provides support for the definition of multidisciplinary projects supervised jointly by lecturers from different disciplines, so that the problems being addressed can be approached with an integral perspective, which would undoubtedly bring a high educational value.

Finally, centralizing a significant number of ApS programs through Virtu@lApS will provide a large amount of valuable data for research in ApS, in particular, regarding its academic impact.

\section{FUTURE WORK}

We trust that our incremental development approach will ensure the availability of a first operative version of our application relatively early. Once this version is implemented, we hope that its usefulness will become clear and the continuity of the project will then be guaranteed.

For the continuation of the development of the SL support environment, viewed as an SL project, our objective is to ensure that assessment is present throughout and that all the actors involved participate in this assessment. In principle, we propose to assess both the participation of all actors - the beneficiaries of the 'SL support environment' service (SL-service providers and SL-service beneficiaries) and the providers of the 'SL support environment' service (student developers and their supervisors) - and the reciprocity of the service-learning between providers and beneficiaries, in short, the different aspects highlighted in García-Gutierrez and Ruiz-Corbella (2019), using measurement instruments selected from among those compiled in the aforementioned work.

The VSL methodology currently used by COETIC is still immature, and its further development will undoubtedly give rise to new methodological tools and technological support for them that will then be translated into new requirements for the Virtu@l-ApS application. Reciprocally, progress with the application will favour the success of the SL projects implemented using the application, for example by reliably evaluating important dimensions of learning in the international VSL projects promoted by COETIC.

Regardless of the technological aspects, it will be necessary to draw up and implement an application deployment plan that will involve, among other things, establishing contacts and agreements with NGOs, and with different university departments for collaboration in the management of multidisciplinary projects. These can be considered requirements for the provision of the 'SL support environment' service viewed itself as an SL project. Also pending is the definition of 
a methodology for the management and development of multidisciplinary projects (bachelor's degree projects, master's degree projects/theses, and doctoral theses), with emphasis on collaboration and on-line monitoring.

In the medium term, it will also be useful to evaluate the impact of the project on the educational institutions involved. It is to be hoped that as a result of the tasks involved in the development of the web application being shared by many different actors, collaborations and synergies will arise for the research and practice of SL.

In the longer term, it will be pertinent to evaluate the quality and impact of the service provided, that is, to assess if the web application fulfills the essential function for which it was designed: that of contributing to the support and expansion of SL in higher education in Spain.

\section{ACKNOWLEDGEMENTS}

The authors would like to thank Juan García Gutierrez, supervisor of Natalia Rodriguez's degree project and current coordinator of both the COETIC group and the UNED SL office, for his role in defining and promoting Virtu@l-Aps.

\section{REFERENCES}

Alonso, H. (2018). Aplicación de Soporte a una Comunidad Educativa Interesada en el APS Virtual. Madrid: UNED.

Barrett, M. S. (2016). Fostering Undergraduate Spiritual Growth Through Service-Learning. The International Journal of Research on Service-Learning and Community Engagement, 4(1), 291308.

Cummings, A. T., \& Huff, J., \& Oakes, W. C., \& Zoltowski, C. B. (2013, June), An Assessment Approach to Project-Based Service Learning. Paper presented at ASEE Annual Conference \& Exposition, Atlanta, Georgia, USA.

Dewey, J. (2004). Educación y democracia. Madrid: Morata.

García-Gutiérrez, J., Corbella, M. R., \& del Pozo Armentia, A. (2016). Cuando la comunidad se expande: ciudadanía global y aprendizaje-servicio virtual (apsv). Educacion y diversidad $=$ Education and diversity: Revista inter-universitaria de investigación sobre discapacidad $e$ interculturalidad, 10(2), 63-75.

García-Gutiérrez, J., Ruiz-Corbella, M., \& del Pozo Armentia, A. (2017). Developing Civic Engagement in Distance Higher Education: A Case Study of Virtual Service-Learning (vSL) Programme in Spain. Open Praxis, 9(2), 235-244.

George, C., \& Shams, A. (2007). The challenge of including customer satisfaction into the assessment criteria of overseas servicelearning projects. International Journal for Service Learning in Engineering, Humanitarian Engineering and Social Entrepreneurship, 2(2), 64-75.

Heras Colàs, R., Masgrau Juanola, M., \& Soler Masó, P. (2017). The Institutionalization of Service-Learning at Spanish Universities. International Journal of Research on Service-Learning in Teacher Education, 5(1), 85-97.

Jacoby, B. (2014). Service-learning essentials: Questions, answers, and lessons learned. USA: Wiley \& Sons. 
Kolb, D. A. (2014). Experiential learning: Experience as the source of learning and development. New Jersey: FT press.

Lozano, S. (2015). Desarrollo de una Comunidad Virtual de Profesores en el Ámbito de la Educación parael Desarrollo Humano y Sostenible. Madrid, UNED.

Manjarrés, A., \& Pickin, S. (2018, September) Virtual Service Learning in an Advanced Artificial Intelligence M.Sc. Paper presented at 9th Spanish and 1st European Conference on Service-Learning in Higher Education, Madrid, Spain.

Nielsen, D. (2016). Facilitating service learning in the online technical communication classroom. Journal of Technical Writing and Communication, 46(2), 236-256.

Parmentier, E. (2004). Diseño e implementación deunservicio de conexión de la oferta y la demanda de proyectos de fin de carrera de cooperación. Bachelor's degree Project supervised by Mataix, C. Madrid: Universidad Politécnica de Madrid.

Purcell, J. W. (2017). Community-Engaged Pedagogy in the Virtual Classroom: Integrating eService-Learning Into Online Leadership Education. Journal of Leadership Studies, 11(1), 65-70.

Rama, D. V., Ravenscroft, S. P., Wolcott, S. K., \& Zlotkowski, E. (2000). Service-learning outcomes: Guidelines for educators and researchers. Issues in Accounting Education, 15(4), 657-692.

Rodríguez, N. (2017).Virtu@l-ApS. Madrid: UNED.

Rubin, D. L., \& Matthews, P. H. (2013). Learning outcomes assessment: extrapolating from study abroad to international service-learning. Journal of Higher Education Outreach and Engagement, 17(2), 67-8.

Ruiz-Corbella M., \& García-Gutierrez J. (Editors). (2019). Aprendizaje-Servicio. Los retos de la evaluación. Madrid: Narcea.

Ruiz-Corbella M., \& Manjarrés A. (2019). La evaluación por competencias en los proyectos de aprendizaje-servicio. In M. Ruiz-Corbella \& J. García-Gutiérrez. (Editors), Aprendizaje Servicio: los retos de la evaluación. Madrid: Narcea, 97-118. Sánchez-Elvira Paniagua, Á., Luque Pulgar, E., García Cedeño, F., López-González, M., Fernández-Sánchez, M. V., \& Alba, S. (2010). Del diseño a la evaluación en competencias genéricas: Análisis empírico e intervención mediante rúbricas. Report of the project Programa de Estudios y Análisis EA2009-0102.

Schön, D. A. (1990). Educating the Reflective Practicioner: Toward a New Design for Teaching and Learning in the Professions. Wiley.

Steinberg, K. S., Bringle, R. G., \& Williams, M. J. (2010). Service-learning research primer. Scotts Valley, CA: National Service-Learning Clearinghouse.

Steinke, P., \& Fitch, P. (2007). Assessing service-learning. Research \& Practice in Assessment, 2, 24-29.

USAID. (1970). The logical framework approach. final report, contract csd-2510. Technical report of the United States Agency for International Development.

Waldern, L. S., McGorry, S. Y., \& Widener, M. C. (2012). E-service-learning: the evolution of service learning to engage a growing online student population. Journal of Higher Education Outreach and Engagement, 16(2), 123-149. 


\section{ACADEMIC AND PROFESSIONAL PROFILE OF THE AUTHORS}

Angeles Manjarrés Riesco. She has a bachelor's degree in Physics from the Universidad Complutense de Madrid and a PhD in Physics from the UNED. Since 1992 she has been a teacher and researcher at the Department of Artificial Intelligence of the UNED, previous to which she worked in R\&D at Alcatel-SESA. Since 2000, her research has focused on e-learning and she has been involved in educational programs with NGDOs and in integrating service-learning methodology in computing distance education.

E-mail: amanja@dia.uned.es

Address:

Escuela Técnica Superior de Ingeniería Informática

Universidad Nacional de Educación a Distancia

C/ Juan del Rosal, no 16,28040

Madrid (España)

Simon Pickin. Studied Maths at the universities of Sussex, Cambridge and King's College, and Computing at Imperial College and the Universite de Rennes $(\mathrm{PhD})$. A computing teacher and researcher in the private and public sectors in France and Spain for 30 years, he is currently a computing professor at the Universidad Complutense de Madrid. He has been promoting and supervising master's and bachelor's degree projects involving cooperation for development and/or service learning for 15 years.

E-mail: $\underline{\text { simon.pickin@fdi.ucm.es }}$

Address:

Facultad de Informática

Universidad Complutense de Madrid

C/ Prof. José García Santesmases, 9, 28040

Madrid (España)

Hector Alonso Meana. Obtained an undergraduate degree in Information Technology Engineering from the UNED in 2018. He is currently working on analysis and development of software for postal, parcel and airport logistics at Siemens Logistics, S.L.

E-mail: hectoram@gmail.com

Address:

Siemens Logistics S.L.

Ronda de Europa, 5 
Tres Cantos, 28760,

Madrid (España)

Natalia Rodríguez Fernández. Has a higher education certificate in Social Integration, a bachelor's degree in Social Education from the UNED and specialization diplomas in gender equality. She is currently working as a social educator for Spanish local governments.

E-mail: nataliarf 81@hotmail.com

Address:

Ayuntamiento de Las Reguera

Santullano, 1

Las Regueras, 33190

Asturias (España)

Date of receipt: 20/05/2019

Date of acceptance: 22/06/2019

Date of layout: 29/09/2019 